American Political Science Association

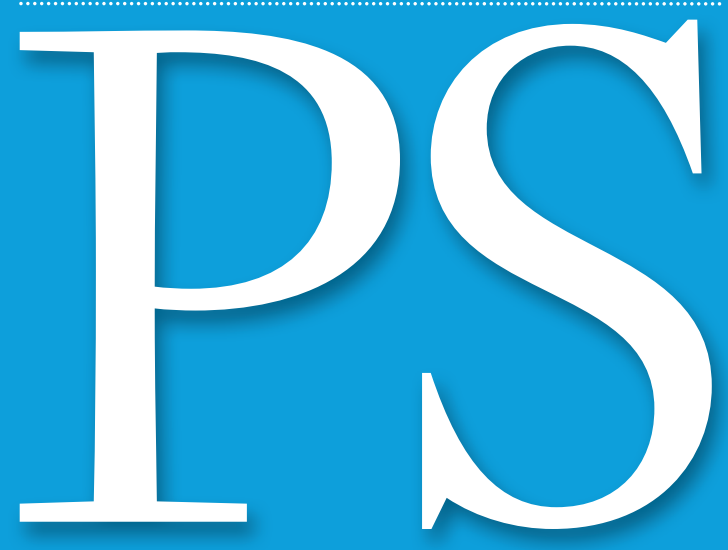

Political Science \& Politics

O с товеR 2014 , Volume 47, Number 4

\section{The 2014 Midterm Election Forecasts}

James E. Campbell, guest editor, with Alan I. Abramowitz, Joseph Bafumi, Robert S. Erikson, Benjamin Highton, Michael S. Lewis-Beck, Eric McGhee, John Sides, Charles Tien, and Christopher Wlezien

\section{Measuring Electoral Integrity around the World}

Pippa Norris, Richard W. Frank, and Ferran Martínez i Coma

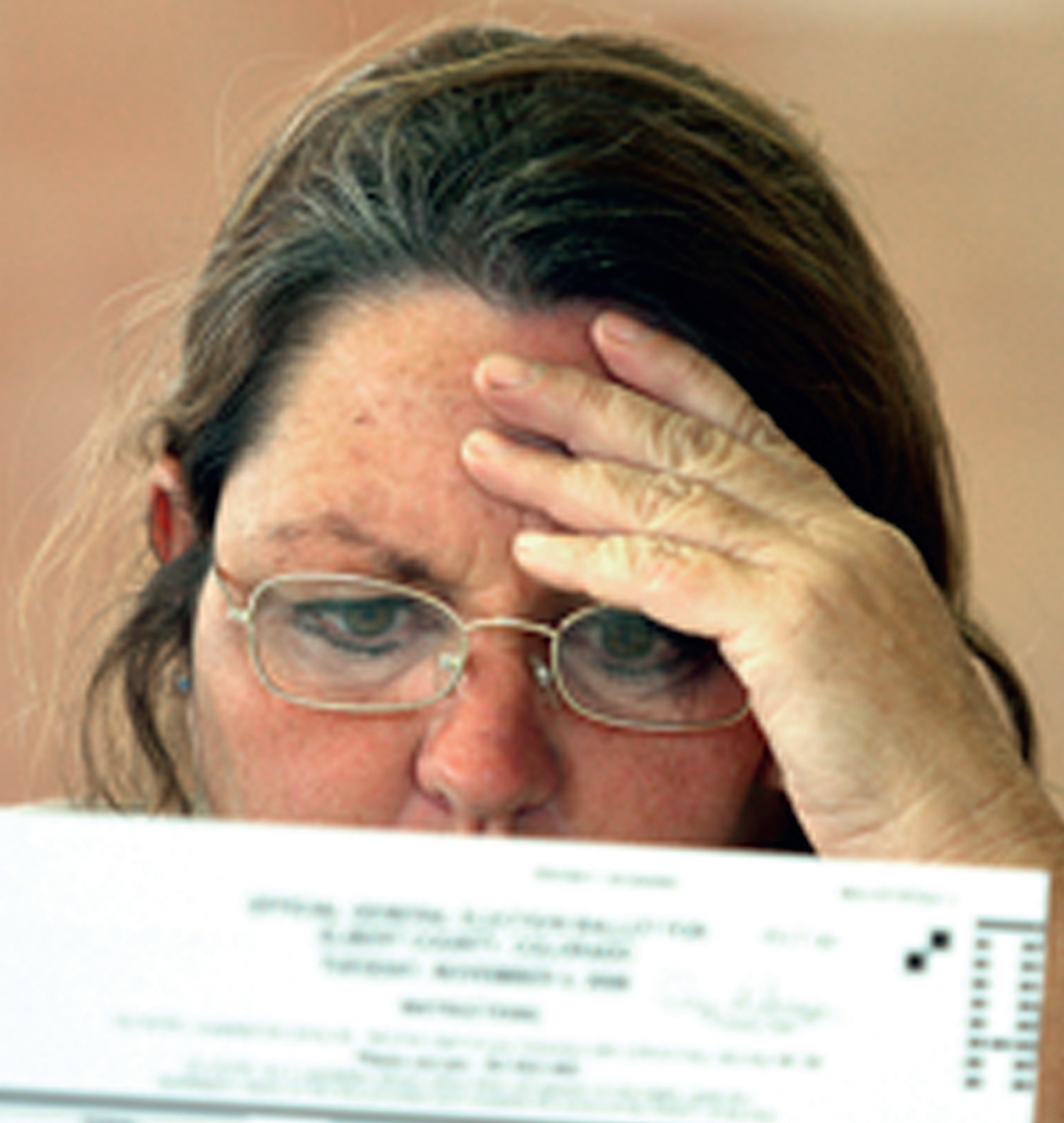


$12^{\text {th }}$ ANNUAL

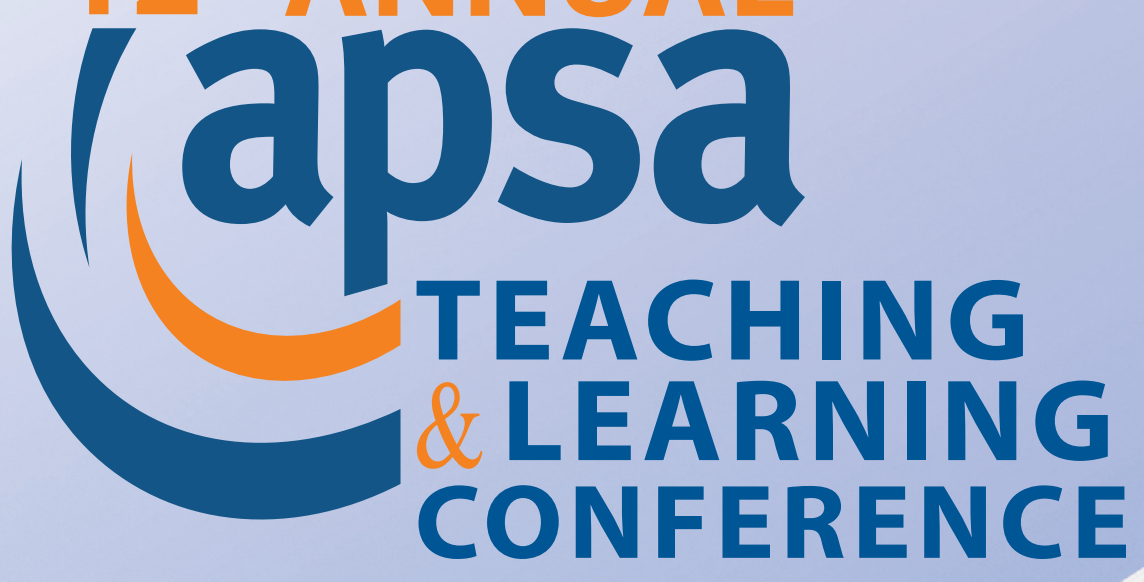

\section{January $16-18,2015$ - Washington, DC}

\section{Washington Hilton}


SYMPOSIUM

769

772

775

782

FEATURES

THE PROFESSION
786 Election Fundamentals and Polls Favor the Republicans

\section{The 2014 Midterm Election Forecasts}

Introduction

James E. Campbell, guest editor

Forecasting the 2014 Midterm Elections with the Generic

Ballot Model

Alan I. Abramowitz

75 National Polls, District Information, and House Seats:

Forecasting the 2014 Midterm Election

Joseph Bafumi, Robert S. Erikson, and Christopher Wlezien

779 The Seats-in-Trouble Forecast of the 2014 Midterm Congressional Elections

James E. Campbell

82 Congressional Election Forecasting: Structure-X Models for 2014 Michael S. Lewis-Beck and Charles Tien Benjamin Highton, Eric McGhee, and John Sides

789 Measuring Electoral Integrity around the World: A New Dataset Pippa Norris, Richard W. Frank, and Ferran Martínez i Coma

799 The Tea Party Movement and the 2012 House Election Andrew D. McNitt

806 Has the Tea Party Era Radicalized the Republican Party? Evidence from Text Analysis of the 2008 and 2012 Republican Primary Debates Juraj Medzihorsky, Levente Littvay, and Erin K. Jenne

813 Political Scandal and Bias in Survey Responses Nicholas Goedert

819 What's a Dog Story Worth? Matthew D. Atkinson, Maria Deam, and Joseph E. Uscinski

824 The Diffusion of Support for Same-Sex Marriage in the US Senate Sean M. Theriault and Herschel F. Thomas III

829 Colleague Crowdsourcing: A Method for Fostering National Student Engagement and Large-N Data Collection Amber E. Boydstun, Jessica T. Feezell, Rebecca A. Glazier, Timothy P. Jurka, and Matthew T. Pietryka

835 Scientific Literacy in Undergraduate Political Science Education: The Current State of Affairs, an Agenda for Action, and Proposed Fundamental Benchmarks Kim Quaile Hill and Rebekah Myers

840 Institutional Review Board and International Field Research in Conflict Zones Srobana Bhattacharya

845 Navigating the International Academic Job Market Nilay Saiya 
THE TEACHER

\section{ASSOCIATION NEWS}

Secondary Students and the Deliberation of Public Issues Patricia G. Avery, Sara A. Levy, and Annette M. M. Simmons

Is It Better to Be Feared Than Loved? Investigating the Efficacy of Different Teaching Methods on the Learning of Specific Content Robert P. Amyot

High-Impact Political Science Internships in a "Low-Density Opportunity" Environment Brian Anderson

Satire and Efficacy in the Political Science Classroom Rebecca A. Glazier

Teaching Canadian Politics and Foreign Policy Onsite:

Benefits and Challenges

James M. McCormick

Is Federalism Still the "Dark Continent" of Political Science Teaching? Yes and No John Kincaid and Richard L. Cole

$$
\text { Campus Teaching Awards, Academic Year 2013-14 }
$$

With news about Pippa Norris, Landry Signé, Katharine Hayhoe, Patrick Kenney, Charles M. Cameron, Robert Huckfeldt, Shanto Iyengar, Paula D. McClain, Ralph Carter, James D. Morrow, and the accomplishments and appointments of more than 300 other political scientists In Memoriam: Tributes to David Easton, Gary William Hoskin, Vincent Lemieux, Jewel Limar Prestage, Thomas P. Trombetas, and Paul P. Van Riper

Through Another Lens: American Democracy Viewed through Race/ Ethnicity and Subnational Institutions Susan E. Clarke

1 Nominations Accepted for 2015 APSA Officers and Council, Awards, and Committees

\section{Briefs}

The Value of the APSA Congressional Fellowship in an Era of Dysfunction Jake Haselswerdt, Jeffrey Fine, Emily Lynch, and Lindsey Herbel

APSA Congressional Fellows 2013-14

Congressional Fellowship Program Announces 2014-15 Fellows

Washington Insider: A Community Approach to Social Science Advocacy Wendy A. Naus 


\section{DEPARTMENTS}

887 People

905

Association News

921

International

924

Gazette

933
Annual Meeting 2014 and Call for Papers Annual Meeting 2015
On the Cover

Pam Holschuh, who lives in rural Elbert County, Colorado, studies her ballot while deciding how to vote at the Russell Gates Mercantile building in the largely Republican Elbert County on November 4, 2008 After nearly two years of presidential campaigning, US citizens went to the polls to vote in the election between Democratic presidential nominee US Senator Barack Obama (D-IL) and Republican nominee US Senator John McCain (R-AZ). (Photo by Marc Piscotty; IStock Photo)

Letters to the Editor Welcomed

Letters via mail or e-mail will be considered for publication in future issues. All submissions should include your name, postal address, daytime telephone number, and e-mail address. Letters will be edited for length and style.

Contact

PS: Political Science and Politics

American Political Science Association

1527 New Hampshire Avenue, NW

Washington, DC 20036-1206

E-mail: ps@apsanet.org

Website: www.apsanet.org/PS/.

Submissions

Guidelines for submitting articles are posted online at www.apsanet.org/PS/.

PS Reprint Permissions

Reprints of $P S$ articles for class use are available through the Academic Permissions Service of the Copyright Clearance Center, 2322 Rosewood Drive, Danvers, MA 01923; phone: (978) 750-8400; fax: (978) 750-4744; or online at www.copyright.com.
EDITOR: Robert J-P. Hauck

MANAGING EDITOR: Barbara Walthall EDITORIAL ASSISTANT: Drew Meadows

\section{EDITORIAL BOARD:}

Matthew R. Cleary, Syracuse University; Heath Fogg Davis, Temple University;

Diana Evans, Trinity College; Rodolfo

Espino III, Arizona State University;

Jennifer Gandhi, Emory University;

Matthew Hindman, Arizona State

University; Liesbet Hooghe, University of North Carolina, Chapel Hill;

Jennifer Jerit, Stony Brook, SUNY; Alisa Kessel, University of Puget Sound; Ari Kohen, University of Nebraska, Lincoln; Kathryn C. Lavelle, Case Western Reserve University; Lori Marso, Union College; Rose McDermott, Brown University; Ronald J. Schmidt, Sr., California State University, Long Beach; and Catherine Warrick, Villanova University.

\section{ASSOCIATION OFFICE ADDRESS AND MEMBERSHIP INFORMATION:}

American Political Science Association individual membership dues are: regular members with income \$200,000 +, \$320; \$135,000-199,999, \$271; \$100,000-134,00o, \$241; \$8o,ooo-99,999, \$207; \$6o,00o-79,999, \$186; $\$ 50,000-59,999, \$ 170 ; \$ 40,000-49,999, \$ 145 ;$ under $\$ 40,000, \$ 98$; retired members $\$ 25,000+, \$ 66$; retired under $\$ 25,000, \$ 40$; targeted international member (TIM), \$40; life member, $\$ 3$,ooo; associate member, one journal, \$62; high school teacher ( $P S$ only), $\$ 45$; student member, $\$ 45$; unemployed member, $\$ 45$. The amount of the dues allocated for a subscription is $\$ 5.75$ for an individual membership.

Changes of address for members should be completed online or mailed to the APSA membership office at: APSA, 1527 New Hampshire Avenue, NW, Washington, DC 20036-1206.

\section{SUBSCRIPTION, PUBLISHING, AND ADVERTISING OFFICE ADDRESS}

Cambridge University Press, 32 Avenue of the Americas, New York, NY 10013-2473; and (outside North America) Cambridge University Press, The Edinburgh Building, Shaftesbury Road, Cambridge CB2 2RU, England.

SUBSCRIPTION INFORMATION: PS: Political Science \& Politics (ISSN 1049-0965) is published in January, April, July, and October by Cambridge University Press for the American Political Science Association. Annual institutional electronic-only subscription rate (2014) is US\$1119 in the United States, Canada, and Mexico, UK£625 elsewhere. Annual institutional printand-electronic subscription rate (2014) is US\$1297 in the United States, Canada, and Mexico, $U K £_{716}$ elsewhere. Periodicals postage rate paid at New York, NY, and additional mailing offices. POSTMASTER: Address changes should be sent to: PS: Political Science \& Politics, Cambridge University Press, 100 Brook Hill Drive, West Nyack, NY 10994-2133, USA.

Copyright (C) 2014 by the American Political Science Association. All rights reserved. No part of this publication may be reproduced, in any form or by any means, electronic, photocopying, or otherwise, without permission in writing from Cambridge University Press. Photocopying information for users in the USA: The Item-Fee Code for the publication (1049-0965/14 $\$ 15.00+\$ .10)$ indicates that copying for internal or personal use beyond that permitted by Sec. 107 or 108 of the U.S. Copyright Law is authorized for users duly registered with the Copyright Clearance Center (CCC) Transaction Reporting Service, provided that the appropriate remittance of $\$ 15$.0o per article is paid directly to CCC, 222 Rosewood Drive, Danvers, MA 01923. Specific written permission must be obtained for all other copying.

ADVERTISING: $P S$ has a circulation of 16,000 . Please contact our Advertising Sales Team at USAdSales@cambridge.org for full advertising information including rates and specs.

composITION: TNQ Books and Journals Pvt. Ltd., Chennai, India PRINTING AND DISTRIBUTION: Dartmouth Printing Co., Hanover, NH. 


\section{About APSA}

Founded in 1903, the American Political Science Association is theleading professional organization for the study of political science and serves more than 15,000 members in over 80 countries. With a range of programs and services for individuals, departments, and institutions, APSA brings together political scientists from all fields of inquiry, regions, and occupational endeavors within and outside academe in order to expand awareness and understanding of politics.

The direct advancement of knowledge is at the core of APSA activities. We promote scholarly communication in political science through a variety of initiatives including publishing three distinguished journals: American Political Science Review, Perspectives on Politics, and PS: Political Science and Politics.

\section{Officers}

\section{PRESIDENT}

Rodney E. Hero

University of California, Berkeley

\section{PRESIDENT-ELECT}

Jennifer Hochschild

Harvard University

\section{VICE-PRESIDENTS}

E. J. Dionne, Jr.

Georgetown University

Brookings Institution

Joanne Gowa

Princeton University

Fredrick C. Harris

Columbia University

\section{TREASURER}

Kathleen Thelen

Massachusetts Institute of Technology

\section{SECRETARY}

Linda L. Fowler

Dartmouth College

\section{PROGRAM CO-CHAIRS}

Layna Mosley

University of North Carolina,

Chapel Hill

Alvin Bernard Tillery

Northwestern University

\section{EDITOR-IN-CHIEF, APSR}

John Ishiyama

University of North Texas

\section{EDITOR-IN-CHIEF,} PERSPECTIVES

Jeffrey C. Isaac

Indiana University

\section{EXECUTIVE DIRECTOR}

Steven Rathgeb Smith

American Political Science Association

\section{Council}

\section{3-2015}

Amrita Basu

Amherst College

Kenneth R. Benoit

London School of Economics

Christine Di Stefano

University of Washington

James N. Druckman

Northwestern University

Hank C. Jenkins-Smith

University of Oklahoma

David C. Kang

Universtiy of Southern California

John M. Sides

George Washington University

Evelyn M. Simien

University of Connecticut

\section{4-2016}

Michelle D. Deardorff

University of Tennessee,

Chattanooga

Maria C. Escobar-Lemmon

Texas A \& M University

Frances E. Lee

University of Maryland, College

Park

David Lublin

American University

Marc Lynch

George Washington University

Tasha Philpot

University of Texas, Austin

David Stasavage

New York University

Mark E. Warren

University of British Columbia

Former APSA Presidents

Frank J. Goodnow

Albert Shaw

Frederick N. Judson

James Bryce

A. Lawrence Lowell

Woodrow Wilson

Simeon E. Baldwin

Albert Bushnell Hart

W. W. Willoughby

John Bassett Moore

Ernst Freund

Jesse Macy

Munroe Smith

Henry Jones Ford

Paul S. Reinsch

Leo S. Rowe

William A. Dunning

Harry A. Garfield

James W. Garner

Charles E. Merriam

Charles A. Beard

William Bennett Munro

Jesse S. Reeves

John A. Fairlie

Benjamin F. Shambaugh

Edward S. Corwin

William F. Willoughby

Isidor Loeb

Walter Shepard

Francis W. Coker

Arthur N. Holcombe

Thomas Reed Powell

Clarence A. Dykstra

Charles Grove Haines

Robert C. Brooks

Frederic A. Ogg

William Anderson

Robert E. Cushman

Leonard D. White

John Gaus

Walter F. Dodd

Arthur W. MacMahon

Henry R. Spencer

Quincy Wright

James K. Pollock

Peter H. Odegard

Luther Gulick

Pendleton Herring

Ralph J. Bunche

Charles McKinley

Harold D. Lasswell

E. E. Schattschneider

V. O. Key, Jr.

R. Taylor Cole

Carl B. Swisher
Emmette S. Redford Charles S. Hyneman

Carl J. Friedrich

C. Herman Pritchett

David B. Truman

Gabriel A. Almond

Robert A. Dahl

Merle Fainsod

David Easton

Karl W. Deutsch

Robert E. Lane

Heinz Eulau

Robert E. Ward

Avery Leiserson

Austin Ranney

James MacGregor Burns

Samuel H. Beer

John C. Wahlke

Leon D. Epstein

Warren E. Miller

Charles E. Lindblom

Seymour Martin Lipset

William H. Riker

Philip E. Converse

Richard F. Fenno

Aaron B. Wildavsky

Samuel P. Huntington

Kenneth N. Waltz

Lucian W. Pye

Judith N. Shklar

Theodore J. Lowi

James Q. Wilson

Lucius J. Barker

Charles O. Jones

Sidney Verba

Arend Lijphart

Elinor Ostrom

M. Kent Jennings

Matthew Holden, Jr.

Robert O. Keohane

Robert Jervis

Robert D. Putnam

Theda Skocpol

Susanne Hoeber Rudolph

Margaret Levi

Ira Katznelson

Robert Axelrod

Dianne M. Pinderhughes

Peter Katzenstein

Henry E. Brady

Carole Pateman

G. Bingham Powell, Jr.

Jane Mansbridge

John H. Aldrich 